\title{
LIBROS/
}

\section{Conquistadores y exploradores en América Central: continuidades y rupturas, de J. Manuel Gómez'}

\section{Adriano Corrales Arias² Tecnológico de Costa Rica}

El texto que nos honra presentar (Gómez, J Manuel: Viajes coloniales por América Central, continuidades y rupturas, Editorial Tecnológica, San José, 2013) es producto de una tesis de postgrado del autor. La originalidad del mismo consiste en poner a "dialogar" los escritos (relaciones de viaje) de cuatro exploradores que atravesaron el istmo de América Central entre los siglos XVI y XVII; dos de ellos españoles (Vasco Nuñez de Balboa, Juan Vázquez de Coronado) y dos ingleses (William Dampier, John Cockburn), en momentos cronológicos diferentes (1500-1860).

De tal forma que se nos ofrece una polifonía interpretativa desde una perspectiva bilingüe, donde sobresalen las visiones española e inglesa, sobre la conquista y sus contradicciones; pero, además, se nos presenta la mirada de aquellos exploradores en torno a los nativos de estas tierras, subrayando las diferencias de aprehensión y diferenciación. Es decir, se reinterpreta el istmo centroamericano en sus primeras luces coloniales, en términos de los paisajes geográficos y humanos, pasando de lo mítico a lo material.

Por lo demás, desde imágenes "científicas" y literarias se despliega la disputa territorial entre ingleses y españoles; mejor dicho, desde la doxa o cosmovisión europea en las vertientes hispana y anglosajona. Así, el istmo se transforma en un campo de batalla epistemológico y discursivo, además del propiamente físico: la lucha por la Moskitia y por mercancías en el Caribe. A partir de esa batalla se producen y reproducen nuevas imágenes y sujetos. Dicho de otra manera, el libro penetra en la guerra imperial, en sus producciones epistémicas y sus relaciones de poder desde una región en construcción a partir del nacimiento de la modernidad y su geopolítica; profundiza y explica el proceso de colonización imperial desde dos perspectivas de matriz europea: la española y la inglesa.

Las descripciones de los exploradores y colonizadores poseen un sustrato proto-etnográfico y antropológico de primera mano, pues el cuerpo en relación con el espacio ocupa un lugar preponderante dando origen a lo que hoy se conoce como corpopolitica (hegemonía de una "raza" sobre otras etnias, o racialización de la historia y de la economía (según Ramón Grosfoguel y Aníbal Quijano). En ese sentido el libro aporta a la continuidad y ruptura de imágenes geográficas y humanas, tanto físicas como escritas, a lo largo de dos siglos de historia colonial.

Su aporte a los Estudios Culturales costarricenses y centroamericanos (latinoamericanos en general) es evidente, pues regresa a la noche colonial para brindar una reinterpretación de la construcción sociocultural e ideológica, hispano-anglosajona, de los territorios que hoy conforman América Central. Su aporte fundamental estriba en ir a las fuentes desde donde nace una visión idílica e impostada de una realidad (centro) americana que reñía con las concepciones europeas apriorísticas, procedentes de la Ilustración y del nacimiento de la Modernidad. En otras palabras, demuestra cómo se fue reconfigurando el discurso colonial y cómo éste fue moldeando tanto el pensamiento

Recibido en 15-09-2013 y aprobado 18-11-2013.

Ver currículum en página de colaboradores. 
de los colonizadores como la forma de auto percibirse de los sujetos coloniales (centroamericanos). Esto permite reconocer las tácticas y estrategias culturales tanto del colonizador (dominio/represión) como del colonizado (sumisión/resistencia).

Todo ello redunda en una nueva comprensión de las fronteras geográficas y socioculturales centroamericanas desde la colonia, donde los territorios quedan catalogados (censo de recursos naturales y humanos) y reclamados dentro del imperio español (de allí la insistencia inglesa de apropiarse de los mismos). Es decir, remite al inicio de un proceso globalizador de repartición y disputa de territorios y mercados que todavía no termina, con todos los procesos transculturadores que acrecientan las tensiones, las rupturas y las discontinuidades.

Se expone, en última instancia, la complejidad de las fronteras ístmicas y la problemática de regiones no integradas al imperio español, ni a la era republicana, caso de la Moskitia, las Islas de la Bahía en Honduras y/o Belice. Todo ello en una mezcla de disciplinas modernas (etnografía, geografía, antropología, historia, economía, etc.) desde el relato de viajes (cuasi relatos, o novelas autobiográficas, aunque documentos no ficticios al fin) pero sin que se consideren como anales, biografías, ni tampoco historia propiamente dicha como disciplina científica. Sin embargo, a partir de esas relaciones de viaje se reconstruye (desde la desconstrucción del investigador), de variadas maneras, todo un mundo y una memoria cultural. Es decir, además de mapas, bitácoras, cartas, confesiones, memorias, testimonios e historias individuales, son historia colectiva y global.

Por lo demás, esos documentos pueden considerarse como la alborada de la literatura moderna centroamericana de matriz europea, así como los primeros indicios de las Ciencias Sociales, o Estudios Culturales, que dieron cuenta (Entomología sociocultural) de los espacios humanos y geográficos durante la conquista y la colonia en el istmo centroamericano. Todo ello con una mixtura de sujetos que entran y salen del discurso hegemónico.

Desde el punto de vista formal y metodológico el texto despliega profusión de datos y de interpretación de los mismos. Los índices son completos, igual que una lista de mapas. Además, está apoyado en una abundante bibliografía. Su estructura (4 grandes capítulos) divididos en apartados temáticos, está bien armada y organizada, y conlleva a unas conclusiones necesarias y propicias; en otras palabras, hay un equilibrio, una proporción y una coordinación notables.

La sustentación teórica es muy sólida dado que exhibe un marco epistemológico amplio y congruente con el objeto de estudio. Se nota un conocimiento exhaustivo de las obras citadas y consultadas y un dominio del tema, así como de trabajos relacionados con el mismo necesarios a la arquitectura del texto. Hay, además, un alto índice de imparcialidad en el tratamiento de los tópicos y en la opinión del autor sobre otros autores y obras relacionadas. $\mathrm{Su}$ grado de información es profundo, además del conocimiento lingüístico, pues domina ambos idiomas (español e inglés), necesarios para la lectura del corpus (textual) investigativo. La claridad y calidad expositivas son estupendas.

Por su alto valor cognitivo y cultural, no cabe duda de que esta será una obra de consulta obligada para académicos, estudiantes e investigadores, dados sus aportes a la comprensión de la historia regional y de los "inicios" de los estudios culturales en el istmo centroamericano. Es un aporte fundamental para la comprensión de nuestro universo sociocultural en perspectiva histórica debido al alto valor agregado en términos de las disciplinas que toca y sugiere.

San José, Costa Rica. 